Generally, ostomy is a purposeful connection of the lumen of the intestine with abdominal integuments by surgery. The study presents practical solutions related to care for the colostomy patient, i.e. an ostomy on the large intestine. The following issues will be discussed: regulating the defecation cycle, risk connected with improper selection of ostomy equipment, instruction on colostomy irrigation with practical advice and irrigation equipment supply. The knowledge of these rules and mastering them in practice is to provide ostomy patients not only with highest-standard care and help but also to prepare them for dealing with problems independently, i.e. for self-care.

Key words: the rules of changing the equipment, irrigation.

\section{Selected problems associated with the treatment and care for patients with colostomy - part 2}

\author{
Katarzyna Muzyczka', Hanna Kachaniuk ${ }^{12}$, \\ Zdzisława Szadowska-Szlachetka ${ }^{1}$, Marianna Charzyńska-Gula', \\ Katarzyna Kocka ${ }^{1}$, Agnieszka Bartoszek ${ }^{1}$, Jolanta Celej-Szuster ${ }^{3}$
}

${ }^{1}$ Chair of Oncology and Community Health Care, Medical University of Lublin, Poland 2Department of Nursing, PWSZ Krosno, Poland

${ }^{3}$ Chair and Department of Neurological Nursing, Medical University of Lublin, Poland

\section{The rules of changing the ostomy equipment for patients [1-3]}

All the necessary accessories should be prepared (the ostomy pouch, the model for measuring the ostomy, scissors, tissues or pads and a bowl with warm water, a bag for waste, and other accessories, if necessary). All the activities should be performed in a hygienic, clean and careful, but not sterile manner. Faeces are not sterile, and the visible intestine is not a wound.

1. Expose the spot on the skin where the ostomy pouch is located (in order to hold the clothes during the change of the ostomy equipment, you may use a clothespin or a safety pin).

2. If you use pouches which can be reused after emptying, first empty the pouch from the intestinal matter. If you use closed pouches, the lower edge of the pouch should be cut and the contents of the pouch should be removed to the toilet.

3. Smear the skin with a moist pad in order to make it easier to remove the ostomy pouch.

4. Detach the used ostomy pouch, starting from the top, pull the adhesive downwards, at the same time holding the skin with the use of special moist gauze pads.

5. Clean the ostomy and the surrounding skin with soft gauze and warm water or moist tissues or soft paper towels (touching the ostomy is not dangerous or painful). Slight bleeding of the delicate mucosa of the visible intestine or the edge of the skin directly surrounding it is permissible if it does not occur too often (every day or every $2-3$ days) and is not too strong (a trickle of blood). However, if blood comes from the inside of the intestine or the excreted stool includes blood, you should see a doctor. If the skin around the ostomy is hairy, in order to quickly remove hair, it is best to use disposable razors in order to avoid potential infection. It is not recommended to use creams, foams, shaving gels or depilation creams (they can cause skin irritation).

6. The skin should be carefully dried.

7. You should remember to remove the foil or paper from the ostomy pouch (the one-part system) or the plate (the two-part system) before attaching them. In order to adhere the plate to the skin, you should hold it for approx. $30 \mathrm{sec}$ onds, trying to attach it closely to the skin.

8. In the two-part system, the most important criterion for choosing the appropriate size of the pouch is the size of the plate which is attached to the skin. Both circles should be of the same size and fit each other, i.e. if the plate has a size "up to $35 \mathrm{~mm}$ ", the pouch should be the same size. Only then will the connection of the pouch with the plate be proper, i.e. tight and reliable.

9. Before putting the pouch on the plate, its walls should be slightly spread so that some air can come inside. 
10. The pouch should be attached to the plate starting from the bottom and moving upwards in a circular motion. One of the producers claims that in the two-part system with rings, the pouch is attached to the plate properly when the rings click. There are also products available in which it is possible to see through the transparent ring of the pouch whether it is properly attached to the transparent ring of the plate.

11. The emptied ostomy pouch and all used pads and tissues should be put in an additional foil bag and thrown in the dustbin. The ostomy pouch should not be thrown in the toilet. One should also remember to always carry a case with the ostomy equipment and necessary accessories.

The ostomy equipment for travelling includes: a clothespin (to hold the clothes), moist and dry gauze pads, a hand washing set, preferably the one-part system (particularly recommended by producers for travelling) and a foil bag for all materials used for changing the ostomy equipment: the ostomy pouch, pads or tissues.

\section{What may happen when the ostomy equipment's size is wrongly adjusted?}

Selecting a plate with too small size in relation to the size of the ostomy causes the necessity to cut too large an outlet in relation to its size. Then, the margin between the outlet in the plate and the plastic ring for attaching the pouch is too small. This makes it difficult to adhere the plate to the skin directly around the ostomy, i.e. where it is the most important. Correspondingly, the adhesive of the one-part pouch in which the outlet is too large, i.e. outside the margin marked on the protective paper, will not hold the skin as long and well as it should. Improper choice of the equipment's size in proportion to the size of the ostomy can thus lead to decreased connection to the skin and a reduced time of adhering to the stomach, and can cause one of the most frequent complications, i.e. skin inflammation around the ostomy. Improper matching of the size of the equipment to the size of the fistula can be equally unfavourable as its improper cutting [4].

\section{Regulating the defecation cycle in patients with a colostomy}

In this case two methods are applied:

The first comprises leading a very regular lifestyle. This mainly implies regular meal times and their number (3-5 meals consumed in a calm atmosphere), regular sleeping times, systematic physical activity and a proper amount of water drunk daily. Such a regular lifestyle can induce regular defecation hours not only in ostomy patients but in all persons $[2,5]$.

The second method involves systematic irrigation of the ostomy. Such procedures, if performed every day, ensure total control over defecation (during the irrigation). The patients who apply irrigation can wear small and very discrete pouches [2].

\section{The rules of ostomy irrigation}

Irrigation is a procedure clearing the large intestine from faeces with the use of a water enema. It makes it possible to directly control passing stool and releasing gases. The procedure is carried out using a special irrigator. Irrigation is possible in the case of both single-barrelled and double- barrelled ostomy on the large intestine (irrigation of the afferent loop). Nearly forty years ago colostomy irrigation was performed with long rubber catheters or other non-elastic materials, which often led to intestine perforation, sometimes ending with the patient's death. The cone currently used for irrigation is a recent development. Its history dates back to 1972. The cone makes it possible for water to flow in the right direction, without spilling [6].

The first irrigation can be performed after surgery, before the patient leaves the hospital or, what happens more often, 1-3 months after the operation during a visit to the stoma clinic $[5,7]$. It is best for the patient to perform the first irrigation under the supervision of an ostomy nurse. After the first several procedures the patient may feel discomfort and be discouraged. The nurse should educate the patient, correct potential mistakes, motivate and support in performing the irrigation on their own. On average after 2-3 weeks the patient is able to carry out the irrigation and perform the procedure routinely. Irrigation performed every day at a fixed time, e.g. after breakfast, can after some time lead to spontaneous evacuation of faeces from the large intestine as a reflex [8]. Irrigation requires regularity. After a properly performed irrigation, the faeces receiver remains clean for 24-28 hours (or even up to 72 hours) so irrigation decreases the amount of ostomy equipment used [9]. With an economical approach, the costs of ostomy equipment can be lowered by one third [8]. Irrigation is usually necessary every 1-2 days, at a specified time, and lasts approx. 2030 minutes. Pouring water into the ostomy, according to the persons using irrigation, takes approx. 5 minutes.

The irrigation set consists of: 1) a plastic water bag, 2) tubes, 3) a clamp (knob) regulating the water flow, 4) coneshaped endings, 5) irrigation sleeve, 6) several clips, 7) a lubricant, 8) a waste bag, 9) dry tissues and possibly other accessories, 10) bottles of non-carbonated mineral water (in the case of travel). Some containers have an inbuilt thermometer which shows the temperature of the water. Containers have a millilitre scale. The irrigation sleeve is a long matt or transparent plastic bag, open from the top and from the bottom $[10,11]$.

\section{The way of carrying out irrigation at home $[6,10,12-15]$}

The first irrigation should be performed in a calm atmosphere, for instance on a day off from work. Because irrigation lasts on average approx. 30 minutes, patients can take their favourite book or music with them (the first irrigation may last more, even an hour). Before starting the irrigation, all the necessary parts of the set should be gathered. The time of performing the procedure must be permanent, preferably $0.5-1$ hour after breakfast.

- There should be a hook in the toilet room in order to hang the container with water. The container should be hung on the hook in such a way that the lower part is at the height of the patient's arm in a standing position (some instructions state that it should be at arm's length of the patient in a sitting position). On the tube there is a water flow regulator in case the water flows too fast. 
- The water container should be connected to the tube with a knob regulating the water flow in the tube leading to the cone.

- The container should be filled with running water at body temperature $\left(37^{\circ} \mathrm{C}\right.$ or slightly cooler). The norm is from 0.5 to 1 litre of water. During the first irrigation the amount of water should be decreased to 300-500 ml.

- Then remove the ostomy pouch. If the skin around the ostomy is dirty, it should be cleaned and the irrigation sleeve should be attached. Before starting the irrigation, remove the air by opening the flow regulation clamp. The bubbles should be removed by the water flowing through the tube and by gentle tapping on the tube walls.

- You should sit on the toilet seat in such a way that the lower part of the sleeve is directly above the water surface to allow the intestinal matter to flow directly to the toilet.

- Lubricate the cone with water in order to make its insertion easier and put it gently into the ostomy through the outlet in the sleeve. Hold the cone firmly with one hand, and open the clamp with the other hand so that the water can flow with the proper speed. When the sufficient amount of water flows to the cone, close the clamp. After that remove the cone, which can cause some water and faeces to flow to the sleeve.

- In order to allow free motion, the sleeve should be rolled upwards and pinned in the upper part with clips contained in the set. Usually after 20-30 minutes the contents of the intestine flow to the sleeve. Sometimes changing the position from sitting to standing will cause small amounts of faeces to exit the ostomy. The faeces' consistency will first be solid; then it will become more watery. At the end the faeces may have a very strong smell and there probably will be more gas. When the intestine is clear, tissues or lignin will be necessary in order to clean the ostomy from faeces remains.

- Then the sleeve should be removed, and the ostomy and the skin should be cleaned with warm water and dried with soft tissue. Before applying new ostomy equipment you should make sure that the skin is dry.

- All irrigation accessories should be disconnected and cleaned. Dry the water container thoroughly. The irrigation sleeve and the used ostomy equipment should be placed in a waste bag and thrown in an ordinary dustbin.

After emptying the ostomy it is recommended to take a whole-body shower. If there is no stool for a day or the next few days (it can be even $72 \mathrm{~h}$, depending on the amount of food consumed and physical activity), during day or night time, it means that the reflex is properly developed.

\section{Possible complications during the intestine irrigation [10]}

- If the water does not flow to the intestine, you should make a circular move with the ending of the irrigator in the exposed ostomy, wait a moment and relax, be careful not to pour water too fast; if this does not help, check whether the irrigator's ending is blocked by intestinal matter, massage the stomach, walk for a while, or put the container with water higher, always remembering to handle the ostomy carefully.
- The water is inside but it does not flow out. It may happen that the intestine of the person with the ostomy is dehydrated. Usually drinking a few glasses of water helps.

- Intestine spasms. The person should be advised to relax and massage the stomach gently.

- The water flows out immediately after removing the cone. This may mean that the cone is removed too quickly. The cone should be held in the ostomy for at least $30 \mathrm{sec}$ onds. Sometimes the person with the ostomy may feel that the pressure is decreasing. This means that the water reaches the upper parts of the intestine.

- Persons undergoing chemo- or radiotherapy should consider waiting approx. six weeks from the end of the treatment in order to start irrigation. Usually the alimentary system is deregulated then.

- A tingling feeling in the intestines. Usually too cold or too hot water, air bubbles from an under-aerated tube. This causes excessive intestinal activity, thus the tingling.

- The possibility of mechanical damage of the intestine. Therefore, the irrigation should be performed with due care.

\section{Contraindications for irrigation:}

- diarrhoea or an active disease (ulcerous inflammation of the large intestine, Crohn's disease or diverticulum inflammation),

- ileostomy - a fistula on the small intestine,

- improper fistula (two hernias around the ostomy, considerably contracted ostomy),

- chemo- and radiotherapy (periodically not recommended until regulating the alimentary system) [16].

In order to prevent loud gas release, a reliable home method can be used. For this purpose an approx. 20-centimetre bandage (or gauze) should be prepared and lubricated with mineral jelly. Then half of the bandage (approx. $10 \mathrm{~cm}$ ) should be put in the ostomy, and the remaining part in the ostomy pouch. This should reduce the loudness of gases released [17].

The frequency of medical appointments of the patient after creating an ostomy depends mostly on the type of disease - the cause of creating the ostomy. However, the appearance and the functioning of the ostomy can be checked by the attending physician when necessary. Persons with bleeding ostomies or with changes in the defecation cycle (diarrhoea or constipation) particularly need checkups. The patient must see a physician at least once a quarter in order to meet the formal requirements to receive the ostomy equipment free-of-charge.

The Regulation of the Minister of Health on guaranteed benefits in the scope of medical equipment supply in the form of orthopaedic equipment and assisting means of 29 August 2009 Annex No. 2 (Journal of Laws of 31 August 2009 No. 139 item 1141) defines monthly price limits for ostomy equipment: colostomy PLN 300 (ileostomy PLN 400, urostomy PLN 480). The ostomy equipment is subsidised in 100\% for all patients with an ostomy. Within these limits, a person with an ostomy can receive free of charge the selected ostomy equipment and accessories for ostomy care. An application for the ostomy equipment is issued by a specialist doctor or a primary healthcare doctor. It must be authorised by the competent organisational unit of the National Health Fund. On the basis 
of the authorised application, the patient may receive the ostomy equipment in a specialist medical supply store or in distribution points in hospitals and ostomy centres [18].

It should be borne in mind that the order can be issued for a maximum of three successive months and it is valid until the end of the month for which it is issued (no longer, however, than 30 days from the issue date). Thus, it should be authorised and used as soon as possible - the doctor and the fund cannot extend its validity [19].

The price of the ostomy equipment varies depending on the company offering a given product. The cost of plates ranges from PLN 12 to PLN 18. There are usually 5 plates in a package. The price of ostomy pouches ranges from approx. PLN 6 to PLN 9 for 10 or 30 pieces in a package. Pouches (as some producers provide) are packed in 30-piece boxes. The irrigation equipment is also subsidised and available in stores with ostomy equipment. The irrigation set costs approx. PLN 320.

The authors declare no conflict of interest.

\section{References}

1. Dziki A. Kolostomia i ileostomia - porady i wskazówki. Broszura informacyjna. Warszawa 2008; 10, 12-13, 44.

2. Styczeń P, Kozłowska-Wojciechowska M. Poradnik dla osób ze stomią. Warszawa 2008; 21, 30.

3. Styczeń P. Sprzęt synergiczny (cz. II). Nasza Troska 2011; 2: 20, 21.

4. Szewczyk MT, Cierzniakowska K, Cwajda J, Stodolska A, Jawień A, Banaszkiewicz Z. Opieka nad chorym z raną wokół stomii. Przew Lek 2005; 4: 93

5. Banaszkiewicz Z, Jawień A. Stomie jelitowe. Przew Lek 2003; 10: 91.

6. http://stomia.pl/index.php?action=edu\&sub=porady dostęp 31.08.2011.

7. Woodhouse F. Colostomy irrigation: are we offering it enough? $\mathrm{Br} J$ Nurs 2005; 14: S14-5.

8. http://www.stomia.info.pl/inout/art001.html - dostęp 30.08.2011.

9. - http://www.stomia.info.pl/inout/art003.html - dostęp 30.08.2011.

10. http://www.stomia.info.pl/irygacje.html\#historia dostęp 30.08.2011.

11. Taylor P. Colostomy irrygation - a safe practice? J Clin Nurs 1994; 4: 203-4.

12. Stota J. Irygacja. In: Mam stomię - co dalej? Broszura informacyjna dla osób ze stomią. Warszawa 2005; 14-5.

13. Jawień A. Opieka stomijna. Poradnik dla pielęgniarek ze stomią. Poznań 2009; 21.

14. Karadag A, Baykara ZG. Colostomy irrygation: an important issue for muslim individuals. Asian Pac J Cancer Prev 2009; 10: 1189-90.

15. McConnell EA. How to irrigate a colostomy. Nursing 1990; 20: 78.

16. http://www.poloznictwo.cba.pl/download/Irok/chirurgia/stomie_2.pdf - dostęp 25.10.2011.

17. Jarosz M. Żywienie chorych ze stomią. Wydawnictwo Lekarskie PZWL, Warszawa 2007; 24-25, 43.

18. http://www.mz.gov.pl/wwwmz/index?mr $=m 491 \& m s=0 \& m l=$ $p l \& m i=56 \& m x=0 \& m t=\& m y=131 \& m a=013519-$ dostęp 23.01.2012

19. Sobczak U. Pielęgnacja stomii w pytaniach i odpowiedziach (cz. VI). Nasza Troska 2010; 1: 10.

\section{Address for correspondence}

\section{Katarzyna Muzyczka}

Medical University of Lublin

Staszica 4-6

20-081 Lublin, Poland

e-mail: katarzyna-muzyczka@wp.p

Submitted: $\quad 8.02 .2012$

Accepted: $\quad 20.09 .2012$ 